\title{
Gross hematuria in a case of Wilson disease: Questions
}

\author{
Rajiv Sinha $\cdot$ Shakeel Akhtar
}

Received: 4 August 2011 /Accepted: 5 August 2011 /Published online: 13 October 2011

(C) IPNA 2011

Keywords Hematuria $\cdot$ Wilson disease $\cdot$ Renal tubular acidosis

\section{Case report}

An eight-year-old boy with the primary diagnosis of Wilson disease and maintained on penicillamine was referred to pediatric nephrology for recurrent episodes of gross hematuria. There was no history of vomiting or diarrhea, and physical examination was unremarkable apart from a slightly enlarged liver. Initial urine examination confirmed significant red blood cells (40-50/hpf) even during periods when he was not having gross haematuria. Renal parameters were as follows: serum sodium $(136 \mathrm{mmol} / \mathrm{L})$, potassium ( $3.3 \mathrm{mmol} / \mathrm{L})$, chloride $(111 \mathrm{mmol} / \mathrm{L})$, calcium $(8.1 \mathrm{mg} / \mathrm{dl})$, bicarbonate $(16 \mathrm{mmo} / \mathrm{L})$, albumin $(4.1 \mathrm{~g} / \mathrm{dl})$, and creatinine $(0.6 \mathrm{mg} / \mathrm{dl})$. Serum complements $(\mathrm{C} 3$ and $\mathrm{C} 4)$ were normal, and phase-contrast microscopy of the urine showed no significant dysmorphic red blood cell. His renal ultrasound scan was also reported as normal. Twenty-fourhour urine collection showed insignificant proteinuria (185 mg) but grossly elevated urinary calcium of $215 \mathrm{mg}$ (normal $4 \mathrm{mg} / \mathrm{kg} / 24 \mathrm{~h}=88 \mathrm{mg}$ ). The rest of his urinary electrolytes were as follows: sodium $50 \mathrm{mmol} / \mathrm{L}$, potassium $61.3 \mathrm{mmol} / \mathrm{L}$, and chloride $74.7 \mathrm{mmol} / \mathrm{L}$.

1. What is the likely cause of hematuria?

2. What could be the possible correlation between the primary diagnosis of Wilson disease and hematuria?

3. What further investigations need to be done to confirm the diagnosis?

The answers to these questions can be found at http://dx.doi.org/ 10.1007/s00467-011-2011-x

R. Sinha $(\square)$

Pediatric Nephrology, PGIMER,

Chandigarh, India

e-mail: rajivsinha_in@yahoo.com

\section{S. Akhtar}

Institute of Child Health,

Kolkata, India 